\title{
Badminton Game Empowerment: A Symbol of Leadership in the Student Association
}

\author{
Amat Komari \\ Faculty of Sports Science \\ Universitas Negeri Yogyakarta \\ Yogyakarta, Indonesia \\ amatkomari@uny.ac.id \\ Agus Susworo Dwi Marhaendro \\ Faculty of Sports Science \\ Universitas Negeri Yogyakarta \\ Yogyakarta, Indonesia \\ agus_marhaendro@uny.ac.id
}

\author{
AM Bandi Utama \\ Faculty of Sports Science \\ Universitas Negeri Yogyakarta \\ Yogyakarta, Indonesia \\ bandi_utama@uny.ac.id \\ Raden Sunardianta \\ Faculty of Sports Science \\ Universitas Negeri Yogyakarta \\ Yogyakarta, Indonesia \\ sunardianta@uny.ac.id
}

\begin{abstract}
This study entitled "Badminton game empowerment: a symbol of leadership in the student association of FIK UNY" generally proposes the idea of lecturers in this era being expected to teach in a different manner from their predecessors. Since we are in a new era, lecturers' ability to use current materials is deemed necessary. Here, badminton is popularly known as a game, however, this game has a lot of potential to become one of the ways to reach educational goals. Empowering the game can result into its growth and capability to go beyond various divisions in the society. Empowerment of badminton game is aimed at enriching knowledge and insight into badminton from leadership point of view as needed by all people. Therefore, there will be more badminton enthusiasts and players as many people, including those joining in ORMAWA FIK UNY, need leadership. Badminton-sourced leadership is a relatively new topic which needs more exploration to see how students joining in ORMAWA FIK UNY respond to badminton leadership N7SR.
\end{abstract}

\section{Keywords—badminton, leadership, N7SR}

\section{INTRODUCTION}

To survive, humans require interaction and collaboration with other people in different situations which also includes sports and games. There are numerous games people are able to play, therefore there is a necessary decision on what type of games suits their liking and skill best. The ball games involve either large or small balls [1]. Small ball games includes: table tennis, badminton, tennis, baseball, and rounders. Certain games require cooperation of players involved. Hence, in addition to satisfying human needs to socialize with other people, cooperation also becomes the key motives for playing games. The fact that humans need are countless while there are limited ways of satisfying these needs suggests that humans need other people to satisfy their needs. In playing game such as badminton, an appointment is usually scheduled before playing with partners. When one of the players does not show up, the other players get really disappointed. This is similar to when playing doubles in which players cooperation is needed so they can work together as a cohesive unit and avoid misunderstanding. In real life, rural community values cooperation strongly. For example, when a woman in a family lacks spices to cook, she will simply ask her neighbor for the spices she needs.

In modern community, cooperation and involvement in the society are getting more complex as a result of people having multiple and more extensive roles in their community, company and organization. In such situation, people working in healthcare, educational, industrial, governmental fields and other organizations which include student association in higher education institutions need effective and efficient management.

For effective and efficient management to be properly conducted, leadership must exist. Leadership involves both leaders and members in the organizations seeing their leaders as figures who are capable of managing their organization. The leaders need to (1) set goals, (2) allocate resources they own, (3) focus on company's goals, (4) organize changes, (5) build interpersonal relation, and (6) set the right direction [2]. The leadership is translated into terms of traits, personal behavior, influence on others, patterns, interactions, cooperative relationships between roles, position of an administrative office, and persuasive, and perceptions from others about the legitimacy of influence [3].

In addition to that, for a specific period of time, a good organization usually sets clear job descriptions and tasks for each division. A leader possess strengths other people do not have and therefore are able to give solutions to the problems. People put great expectation on their leaders and therefore see them as an idol. Leaders are copied and anything they do is believed in.

A satisfaction or dissatisfaction gained from overall working experiences influences people's evaluation of effective or ineffective leaders [2]. The Satisfaction can either be material or immaterial. An example of immaterial satisfaction is seen when a cleaning service officer feels happy when his boss shows him some support by patting him 
on the back. This singular action shows intensive interaction between leaders and their employees at work.

The leadership is translated into terms of traits, personal behavior, influence on others, patterns, interactions, cooperative relationships between roles, position of an administrative office, and persuasive, and perceptions from others about the legitimacy of influence [3].

A leadership is an activity to influence people to be directed towards achieving organizational goals. Leadership includes the process of influencing in determining organizational goals, motivating follower behavior to achieve goals, influencing to improve the group and culture [4], while leadership is a process of social influence in which managers seek voluntary participation from subordinates in an effort to achieve goals organization [5]. With leadership conducted by a leader also describes the direction and goals to be achieved from an organization. So that it can be said that leadership is very influential for the big name of the organization. In the leadership model of Locke, et al, 1991, it can be seen that the factors that must be possessed by the leader are the reasons and traits / motives and traits as well as knowledge, skills, and abilities / KSAs needed to build a vision and implement the vision. Here the approach used by Locke is the nature approach.

The states that leadership also has a power, behavior and situational approach in addition to the nature of the approach [6]. The leadership is defined in terms of individual traits, leader behavior, interaction patterns, role relationships, subordinate perceptions, influence over subordinates, influence on task objectives, influence on effective leadership organizational culture often evaluated in organizational adaptation with environmental changes. A number of positions of power for effective leadership depend on the nature of the organization, task, and subordinates. There are five bases of power, namely: - Legitimacy power: one's ability to influence others because of his position. - Power Rewards: power based on one's ability to reward others (followers) for their obedience. - Coercive power: punishment power. Punishment is all the consequences of actions that are felt unpleasant for the person who receives it. Giving punishment to someone is intended also to modify behavior, punish bad behavior / harm the organization with the intention to turn into useful behavior, expert power [6].

Someone has expert power if he has special skills that are highly rated. - The role of the role model. Many individuals unite or are influenced by someone because of the style of personality or behavior of the person concerned. The charisma of the person concerned is the basis of the role of the role model. 2. Behavioral Approach. This approach emphasizes that leaders and managers actually work for work and the relationship of managerial effectiveness. The Hundreds study examined the correlation of lead initiating structure and consideration with subordinate satisfaction and performance. A number of studies have found a link between planning and managerial effectiveness, although effective planning is usually informal and flexible rather than formal and rigid Some types of managerial behavior are found to be related to managerial effectiveness.
Approach to Nature. This approach emphasizes the personal attributes of a leader. Research is now trying to link siat with specific role conditions on different types of managerial positions. McClelland's research and others have found that effective leaders are broadly, organizational hierarchies tend to have strong power needs, need for strong achievement, and relatively weaker affiliate needs. An effective manager has a power orientation to socialize with high emotional maturity.

Situational Approach. This approach emphasizes the importance of contextual factors such as authority, leader's wisdom, the nature of work performed by the lead unit, subordinate attributes, and the nature of the external environment. It discussed various kinds of leadership theories such as:

a. Situational Theory for effective leaders consists of: - Path-Goal Theory:

b. Situational Leadership Theory.

c. Leader of the Substitutes Theory

d. Normative Decision Theory

The states that problems in the concept of leadership are aimed at: a. The ambiguity in definition and measurement $b$. Leadership issues affect performance c. Leader selection process. From several leadership studies, the dimensions and definitions of concepts are not clear. Some agree that leadership is related to social influences, more disagreements understand the basic dimensions of leader behavior [7].The state that leadership is an awareness in the process by which one or more individuals replace in an effort to compile and define reality with others. In this case there are people who have an obligation or right to define reality with others.

Leadership as an action, is a man who influences his people without any coercive action [2]. It is clearly seen that one's ability to use his mind and behavior effectively on a daily basis can influence his people to imitating him voluntarily. While their leader is delivering a speech, they listen to him thoroughly. By empowering people in the decision making process, leaders give employees a sense of direction of where they are headed. Culturally, Japanese people never call other people by their names, but they will address them by "mas, bapak, ibu, kang, Pak Lurah, Pak Bupati, or Pak Presiden" to show respect. Calling people only by names shows less respect and can create potential problems. To show great respect towards certain persons,peoplewill call them by a highly respected titlesuch as KanjengNabi Muhammad and never by name only.

Leadership also emerges in student associations "Ormawa" not only in faculty level which include Faculty Students Executive Board (BEMF) and Faculty Student House of Representatives (DPMF) but also in department/study program level which includes Student Union (HIMA). There are four HIMAs in Sports Science Faculty including HIMA PJKR, HIMA PKO, HIMA IKOR and HIMA PGSD PENJAS. The management of Ormawa by UNY aims to channel, develop, and direct the Ormawa in universities, faculties, and departments. There is also Student Activity Unit (UKM) in university level. From the organization's point of view, UKM is assigned to plan, 
execute, and develop any extracurricular activities particularly those related to logical reasoning, hobbies and interests, as well as well-being and special interests. UKM exists to bring together students who share similar hobbies and interests, in order for them to do extracurricular activities in campus. Extracurricular activities are grouped into:

1) Logical Reasoning Department consisting of: (a)Research Club (b)“EKSPRESI” Student Press Club (c) Magenta FM Radio Club (d) Foreign Language Club

2) Art Department consisting of (a)"SICMA BAND” Art Club (b)Literature and Theater Club (UNSTRAT) (c)Traditional Art Club (KAMASETRA) and (d)Fine Art and Photography Club (SERUFO)

3) Sports Department consisting of: (a)Athletic Club (b) Basketball Club (c) Volleyball Club (d)Badminton Club (e)Chess Club (f)Hockey Club (g)Judo Club (h)Karate Club (I) Marching Band Club (j)Nature Club (MADAWIRNA) (k)Archery Club (l) Martial Art Club (m)Swimming Club (n) Football Club (o)SepakTakraw Club, (p) Softball Base Ball Club (q) Tae Kwon Do Club.

4) Well-Being Department consisting of: (a). Cooperative Club"KOPMA UNY" (b)Islamic Religion Club (UKKI) (c)Catholic Religion Club (IKMK) (d) UKM Christian Religion Club (e)Hindu Dharma Student Club (KMHD)

5) Special Interest Department consisting of: (a). Scott Club "Pramuka Racana WR Supratman and Racan F Fatmawati" (b). Student Regiment Club (PASOPATI) (c)Voluntary Red Cross Club "KSR PMI"

Each department is made up of their own chairperson, vice chairperson, secretary, treasury, and divisions who are responsible for specifically assigned tasks. Participating in such organizations allows students to gain a lot of experience in organization management which later provides benefits for the future.

Evidences suggest that students who are actively part of student organizations possess a higher level of skills than the others. They are trained through scientific meetings which helps them in gaining experiences in solving problems. Problem solving skill affects one's behavior positively in solving academic problems and therefore allows the achieve high grade point average while graduating.

Great opportunities to actively participate in student organizations as well as their obligation to focus on their studies intensively teaches the students time management and balance in both academic and organization activities. Students should be able to wisely manage and balance both aspects. To assist the members in the running of the organization, leaders in student organizations should display leadership character. Some types of leadership popularly known are: (1) participative leadership (2) charismatic leadership (3) transformational leadership, (4) transactional leadership (5) Japanese culture leadership (6) Honda-model leadership (7) N7SR badminton leadership, and many others.

\section{METHODS}

\section{A. Research Design}

This study applied a descriptive method which is capable of providing information about current situation i.e the information that we need. This method suits the problems of this study best.

\section{B. Research Instrument}

This study adopted questionnaires as its research instrument. Data were collected using a close-ended questionnaire, comprised of a set of questions wit answer alternatives such as Very Empowering (VE), Empowering (E), Slightly Empowering (SE), and Not Empowering (NE).

\section{Research Subject}

The population, consisting of all students of Sports Science Faculty (FIK) joining in the Student Organization (ORMAWA) has emerged as the subjects in this study.

\section{Data Analysis Technique}

Data in this study were analyzed employing a descriptive statistics technique. Each item in the questionnaire was calculated in percentage. Sugiyono (2010) presented the following formula to be involved in the calculation:

$$
P=\frac{F}{N} \times 100 \%
$$

Where:

$$
\begin{aligned}
& \text { P: Percentage } \\
& \text { F: Acquired Score } \\
& \text { N: Overall Score }
\end{aligned}
$$

Data were then summarized further in a frequency table for categorization. This categorization comprised of 4 (four) categories which includes; Very Empowering (VE), Empowering (E), Slightly Empowering (SE), and Not Empowering (NE).

TABLE I. BADMINTON EMPOWERMENT LEVEL CATEGORIES AS A SYMBOL OF LEADERSHIP, CONSISTING OF 7 NETS, 1 SHUTTLECOCK, AND 1 RACKET (N7SR).

\begin{tabular}{|c|l|l|}
\hline No & Interval & Category \\
\hline 1 & $\mathrm{x} \leqslant 9$ & Not Empowering \\
\hline 2 & $10 \leqslant \mathrm{x} \leqslant 18$ & Slightly Empowering \\
\hline 3 & $19 \leqslant \mathrm{x} \leqslant 27$ & Empowering \\
\hline 4 & $28 \leqslant \mathrm{x}$ & Very Empowering \\
\hline
\end{tabular}




\section{RESULT}

TABLE II. STATISTICS DISTRIBUTION FOR LEVELS OF BADMINTON EMPOWERMENT AS A SYMBOL OF LEADERSHIP, CONSISTING OF 7 NETS, 1 SHUTTLECOCK, AND 1 RACKET (N7SR).

Statistics
\begin{tabular}{|l|l|} 
Amount & \multicolumn{2}{|l|}{$\begin{array}{l}\text { N } \quad \text { Valid } \\
\text { Missing }\end{array}$} \\
Mean & 0 \\
Median & 30.4935 \\
Mode & 31.0000 \\
Std. Deviation & 32.00 \\
Variance & 4.16320 \\
Minimum & 17.332 \\
Maximum & 10.00 \\
Sum & 36.00 \\
\hline
\end{tabular}

To simplify data description, categorization for level of badminton empowerment as a symbol of leadership consisting of 7 Nets, 1 Shuttlecock, and 1 Racket (N7SR) was conducted. The empowerment level was measured using a set of questionnaire comprising 9 valid items. All items included a set of answer options ranging from score 1 to score 4 .

Results of descriptive statistics for level of badminton empowerment as a symbol of leadership consisting of 7 Nets, 1 Shuttlecock, and 1 Racket (N7SR) indicates an overall minimum score of 10, an overall maximum score of 36 , a mean of 30.5 , a median of 31 , a mode of 32 , and standard deviation of 4.16. Frequency distribution is presented in the following table.

TABLE III. FREQUENCY DISTRIBUTION AND CATEGORIES FOR LEVEL OF BADMINTON EMPOWERMENT AS A SYMBOL OF LEADERSHIP CONSISTING OF 7 NETS, 1 SHUTTLECOCK, AND 1 RACKET (N7SR).

\begin{tabular}{|c|c|c|c|c|}
\hline \multirow{2}{*}{ No } & \multirow{2}{*}{ Category } & \multirow{2}{*}{ Interval } & \multicolumn{2}{|c|}{ Frequency } \\
\hline & & & Absolute & Percentage \\
\hline 1 & $\begin{array}{l}\text { Not } \\
\text { Empowering }\end{array}$ & $x \leqslant 9$ & 0 & $0 \%$ \\
\hline 2 & $\begin{array}{l}\text { Slightly } \\
\text { Empowering }\end{array}$ & $10 \leqslant x \leqslant 18$ & 1 & $1.3 \%$ \\
\hline 3 & Empowering & $19 \leqslant x \leqslant 27$ & 16 & $20.77 \%$ \\
\hline 4 & $\begin{array}{l}\text { Very } \\
\text { Empowering }\end{array}$ & $28 \leqslant x$ & 60 & $78 \%$ \\
\hline \multicolumn{3}{|c|}{ Total } & 77 & $100 \%$ \\
\hline
\end{tabular}

In reference to data presented in the above table, 1 respondent $(1.3 \%)$ considered N7SR as slightly empowering, while 16 respondents $(20.77 \%)$ considered N7SR as empowering, and the other 60 respondents (78\%) considered N7SR as very empowering. Frequency of each category suggests that badminton empowerment as a symbol of leadership consisting of 7 Nets, 1 Shuttlecock, and 1 Racket (N7SR) is very empowering.

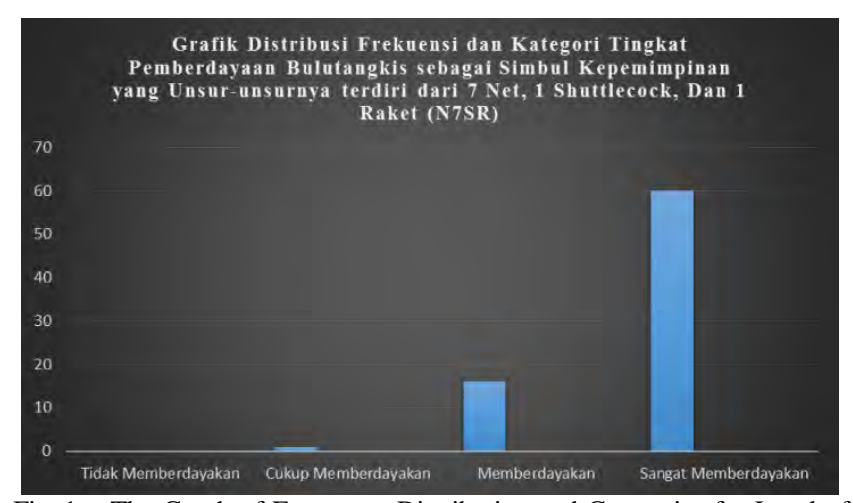

Fig. 1. The Graph of Frequency Distribution and Categories for Level of Badminton Empowerment as a Symbol of Leadership Consisting of 7 Nets, 1 Shuttlecock, and 1 Racket (N7SR).

\section{CONCLUSION}

In sum, data analysis results suggest that students perceive empowerment of badminton $n 7$ sr leadership in ormawa fik uny as very empowering. Results show that 1 respondent $(1.3 \%)$ considered $\mathrm{n} 7 \mathrm{sr}$ as slightly empowering, while 16 respondents $(20.77 \%)$ considered $\mathrm{n} 7 \mathrm{sr}$ as empowering, and the rest 60 respondents $(78 \%)$ considered $\mathrm{n} 7 \mathrm{sr}$ as very empowering.

\section{REFERENCES}

[1] H. Yuliarto, "Pendidikan Permainan: Hand Out Materi PLPG," 2013.

[2] Gibson, Ivencevich, and Donnelly, "Organisasi Perilaku Struktur," Proses: Jakarta Binarupa Aksara, 1997.

[3] Wahjosumidjo, "Leadership, Review of Theories and Problems.”Jakarta: Raja Grafindo Persada, 1997.

[4] M. Toha, "Leadership in management" PT.Raja Grafindo Persada,Jakarta, 2006.

[5] D.Timple, "The Art And Scicien of Business Management Leadership,” Jakarta, PT. Elex media kompotindo, Gramedia, 2002.

[6] G.A. Yukl, "Managerial Leadership: A Review of Theory and Research,” Journal of Management, 14, 251-289, 1989.

[7] J. Pfeffer, "Managing With Power : Politics and Influence Inorganizations," Boston : Harvard Business Press, 1992. 